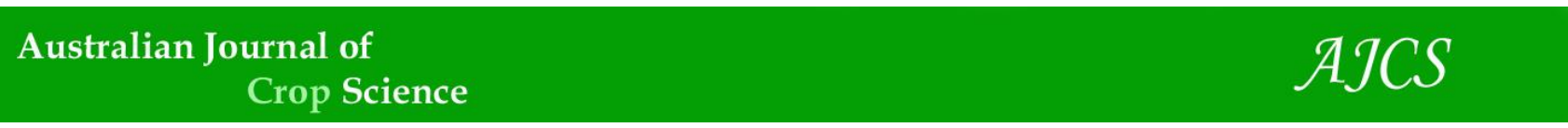

AJCS 14(01):161-171 (2020)

ISSN:1835-2707

doi: 10.21475/ajcs.20.14.01.p2057

\title{
Growth performance of Mission and Kyasuwa grasses (Pennisetum sp.) under different NPK ratios as potential slope cover
}

\author{
Afaff Emhemed Ettbeb ${ }^{1}$, Zulfahmi Ali Rahman ${ }^{1 *}$, Wan Mohd Razi Idris ${ }^{1}$, Jumaat Adam ${ }^{1}$, Sahibini Abd \\ Rahim $^{2}$, Tukimat Lihan ${ }^{1}$, Siti Norhafizah Ahmad Tarmidzi ${ }^{1}$, Nurul Atiqah Mohd Azlam ${ }^{1}$
}

${ }^{1}$ Center of Earth Science and Environment, Faculty of Science and Technology, University Kebangsaan Malaysia,
43600 Bangi, MALAYSIA

${ }^{2}$ Environmental Science Program, Faculty of Science and Natural Resources, Universiti Malaysia Sabah, Jalan UMS, 88400 Kota Kinabalu Sabah MALAYSIA

*Corresponding author: zarah1970@ukm.edu.my; fahmirina@gmail.com

Abstract

The Mission (Pennisetum polystachio) and Kyasuwa (Pennisetum pedicellatum) grasses are common perennial plants found in tropical regions that tolerates low nutrient soils, easily spread by wind and colonization of new areas. It is a great challenge for researchers to select plant species in terms of their performance for vegetation cover to minimize the sloppy soil erosion. Therefore, this study aimed to evaluate the growth performance of selected Pennisetum sp. namely $P$. pedicellatum (PPd) and $P$. polystachio (PPI) under different NPK ratio. The studied species were treated with three different treatments, $F_{1}, F_{2}$ and NF under greenhouse conditions. Hydroseeding technique was adopted for germination of the selected species in the polybags and periodically monitored for a duration of six months. Parameters measured for the growth performance of the studied species were based on plant height, total biomass and chlorophyll content. After application of the treatment $F_{1}$ and $F_{2}$, the soil $\mathrm{pH}$ changed to slightly acidic ( $\mathrm{pH}$ 5.45) while organic content of soil was slightly increased from $3.2 \%$ to $3.9 \%$. A similar result was also found in $\mathrm{N}$ and $P$ nutrient availability of the soil. Meanwhile, available $K$ decreased from $29.76 \mathrm{mg} / \mathrm{kg}$ to $28.41 \mathrm{mg} / \mathrm{kg}\left(F_{1}\right)$ and $23.83 \mathrm{mg} / \mathrm{kg}\left(F_{2}\right)$ for PPI species. This trend was also observed by the PPd species. The PPd species with $F_{1}$ and $F_{2}$ treatments showed higher value of plant height if compared to that of PPI species. In terms of total biomass and chlorophyll content, PPI species treated with both treatments showed higher value than PPd species. Species treated with $\mathrm{F}_{1}$ showed higher value in all growth performance variables (height, dry biomass and chlorophyll content), if compared to that of $F_{2}$ and NF treatments. These findings discovered Pennisetum polystatchion (PPI species) as a potential biological material that can be used as a slope vegetation cover.

Keywords: Pennisetum sp., NPK fertilizer, Hydroseeding, Biomass, Chlorophyll content.

\section{Introduction}

Slope instability commonly begins with feature of slope erosion. Tropical Malaysian climate with apparent wet seasons had greatly caused more severe slope erosions, which then heightened toward landslide occurrence mainly depending on soil type of the slopes (Huat et al., 2007; Qasim et al., 2013). One of the common approaches in combating slope soil erosion was hydroseeding technique. Cereno et al. (2011) and Matthew et al. (2011) found that this approach was fairly efficient for large scaled planting establishments, which involved the utilization of water carrier for the purpose of applying seed under pressure on the soil slopes.

Many of the species used in slope instability improvement were brought in from other regions such as the vertiver grass (Chrysopogon zizanioides), signal grass (Brachiaria decumbens) and Bermuda grass (Cynodon dactylon) (Grimhaw, 1994; Yoon, 1994; Cheng and Zhang, 2002; Kong et al., 2003). There were a variety of local grass species available that could be potentially used as biological material for slope vegetation cover. It would offer advantages in terms of cost and opportunity to introduce local species instead of solely depending on conventional commercial species.

A common plant species found in tropical regions was Pennisetum sp. which belonged to Poaceae family (Ismail et al., 2018). This plant was brought in from Thailand at the end of 1980s. This species was well distributed and has adapted well in this country. Therefore, it could be used as a biological material for slope vegetation, if compared to exotic species (Schnitzler et al., 2007; Normaniza and Barakbah, 2011). Pennisetum sp. can be spread easily by wind and colonization of new areas and undergo rapid multiplication (Ismail et al., 2015). These characteristics were suitable as a pioneering species in order to rapidly dominate a slope even though the soil is in a poor state (Lammeraaner et al., 2005). 
The nutrients necessary for plants to grow exist naturally in the soil. The NPK fertilization served as an alternative source of nutrients that are required by the plants due to insufficient availability in the soil. It was a common practice to promote initial germination of a particular plant by introducing different ratios of NPK at different stages of growth. Nitrogen $(\mathrm{N})$ is an important nutrient for the plants, in which $\mathrm{N}$ is an essential component for synthesis of proteins, nuclic acids, enzymes and promotes vigorous vegetative growth. Therefore, demand for $\mathrm{N}$ by plants is higher compared to the other nutrients. It has been reported that the supply of sufficient amount of nitrogen at the early stages of plant growth is critical for the initiation of leaves and primordial (Lampayan et al., 2010).

Phosphorus $(P)$ is the second vital nutrient in the soil with more widespread influence on both natural and agricultural ecosystems than any other essential plant elements (Fageria et al., 2017). This element plays an important role in plant metabolism, respiration and photosynthesis (Narayana et al., 2018; El-Desuki et al., 2006). We have found that sufficient supply of $P$ can have a huge impact on the final crop yield in maize (Barry and Miller, 1989). Grant et al. (2001) and Nadeem et al. (2011) revealed that plants need adequate amount of $P$ at a very early stage of growth to maximize the plant yield. Most of the terrestrial plants can not survive without potassium (K) (Mengel, 2007). This macro nutrient is essential and plays a major functions in plant cells including enzyme activation, osmoregulation and charge balancing (Wakeel et al., 2011). Wang et al. (2013) also cited that an adequate supply of $\mathrm{K}$ has beneficial effects on maintaining or improving dry mass production, leaf area, water retention and membrane stability, as compared to low $\mathrm{K}$ nutrition under drought stress conditions.

Studies on the utilization of Pennisetum species are rarely reported in terms of its potential for slope vegetation cover, which are limited to several species such as Pennisetum setaceum (Yusoff et al., 2016), Pennisetum clandestinum (kikiyu) and Pennisetum purpureum (napier) (Singh, 2010). Hydroseeding approach was used to germinate the studied species of $P$. pedicellatum (PPd) and $P$. polystachion (PPI) and were routinely monitored up to six months. The objectives of this study were to characterize the physicochemical properties of the soil before and after treatments of different NPK ratios and the effect of NPK on the growth performance of the selected species.

\section{Results and Discussion}

\section{Soil moisture content}

Figure 1. shows the level of soil moisture contents for different Pennisetum $s p$. treated with different NPK fertilizers. The lowest soil moisture content was found in PPI (Pennisetum polystachion) treated with $\mathrm{F}_{1}$ and $\mathrm{F}_{2}$, compared to PPd (Pennisetum pedicellatum)(PPd) and NF (no NPK). The low soil moisture contents could be attributed to the presence of high dense shoot-root biomass of PPI treated with $F_{1}$. It is well-acknowledged that the movement of water through soil medium toward plant tissues and water absorption are associated with the presence of root biomass in the soil (Cairns et al., 1997; Tognetti et al., 2009). Fertilizer can indirectly affect the soil moisture content as higher root biomass found in PPI has a capability to absorb more water than soil with lower root density as found in PPd and NF. Then, the density of root can be directly linked to moisture content of the soil. Kang et al. (2002), also reported that more root biomass attributed to a higher chance to better water uptake by plant roots. However no significant difference was observed in soil moisture content using different treaments in both species.

\section{Soil $\mathrm{pH}$ and soil organic matter (SOM)}

The soil $\mathrm{pH}$ after 6 months application of different NPK fertilizer is shown in Figure 2. The soil $\mathrm{pH}$ for all treatments ranged between 5.20 and 5.40. For NF (control) treatment, $\mathrm{pH}$ values were recorded at lowest value of 5.2 in both species (PPI and PPd). On the other hand, the recorded $\mathrm{pH}$ for $\mathrm{PPI}$ with $\mathrm{F}_{1}$ and $\mathrm{F}_{2}$ treatments were 5.38 and 5.40, respectively. Meanwhile for the PPd species, the $\mathrm{pH}$ showed very similar values for both treatments (5.35 and 5.36). Statistically, in both species the values of $\mathrm{pH}$ was significantly $(p<0.05)$ higher in $F_{1}$ and $F_{2}$ comparing to NF. However, the difference between $F_{1}$ and $F_{2}$ was not significant $(p>0.05)$ in both species. Generally, the application of $F_{1}$ and $F_{2}$ changed the initial soil $\mathrm{pH}$ to less acidic for both species. The $\mathrm{pH}$ for NPK fertilizers were 6.43 and 6.67 for $F_{1}$ and $F_{2}$, respectively (Table 4), whilst the average $\mathrm{pH}$ values of hydroseeding mixture was 5.48 (Table 5). Hubbard et al. (2008) cited that the addition of NPK fertilizers led to the rising of soil $\mathrm{pH}$ after hydroseeding. This positively affects the availability of nutrients such as manganese, iron, zinc and phosphorus (Benbi and Brar, 2009). The pH of soil is one of the significant factors that influences solubility of minerals, microbial activity and plant growth (Epstein, 1997; Garcia-Gil et al., 2004).

The content of soil organic matters (SOM) for PPI and PPd is shown in Figure 3. The SOM content ranged from 3.3 to 3.9 for PPI, while 3.1 to 3.6 for PPd species. These values can be classified as low according to Acres et al. (1975). Figure 3 shows that SOM in the control sample (NF) was higher than those in the $F_{1}$ and $F_{2}$ treatments for both species. This can be attributed to the dead plant components deposited in the soil of NF treatment, which in turn, caused the organic matter content to be higher than in other treatments. The deposit of plant material could be due to lack of nutrients available in this treament (Marinho et al., 2016).

\section{Soil nutrient availability}

The nutrient availability of NPK was recorded at the end of the 6 months period of observation as shown in Figure 4. Application of NPK fertilizer influenced the total $\mathrm{N}$ levels of soil. As illustrated in (Figure 4a), it was apparent that treated soils $F_{1}$ and $F_{2}$ had significant increase in total $N$ levels, compared to untreated soils in both species of pennisetum. PPI species with $F_{1}$ was recorded the maximum concentration of $N(1.01 \%)$, followed by PPd with the same treatment. Higher ratio of $\mathrm{N}$ content within the applied NPK fertilizer (10:8:10) could explain the higher total $N$ observed in $F_{1}$ treatments. It can also be attributed to the higher biological activity including nitrification, which raise the transformation of SOM to soil nitrogen (Garcia-Gil et al., 2004). The concentration of $P$ had the tendency to rise in all treatments, as initial content was very low $(0.32 \mathrm{mg} / \mathrm{g})($ Table 2). It was clearly seen that both species treated with $F_{1}$ 
Table 1. The increment percentage of plant height after 6 months compared to NF (control).

\begin{tabular}{lll}
\hline \multirow{2}{*}{ Treatments } & \multicolumn{2}{c}{ Species } \\
\cline { 2 - 3 } & P. polystachio & P. pedicellatum \\
\hline $\mathrm{F}_{1}(10: 8: 10)$ & $67 \%$ & $93 \%$ \\
$\mathrm{~F}_{2}(5: 5: 7)$ & $32 \%$ & $27 \%$ \\
\hline
\end{tabular}

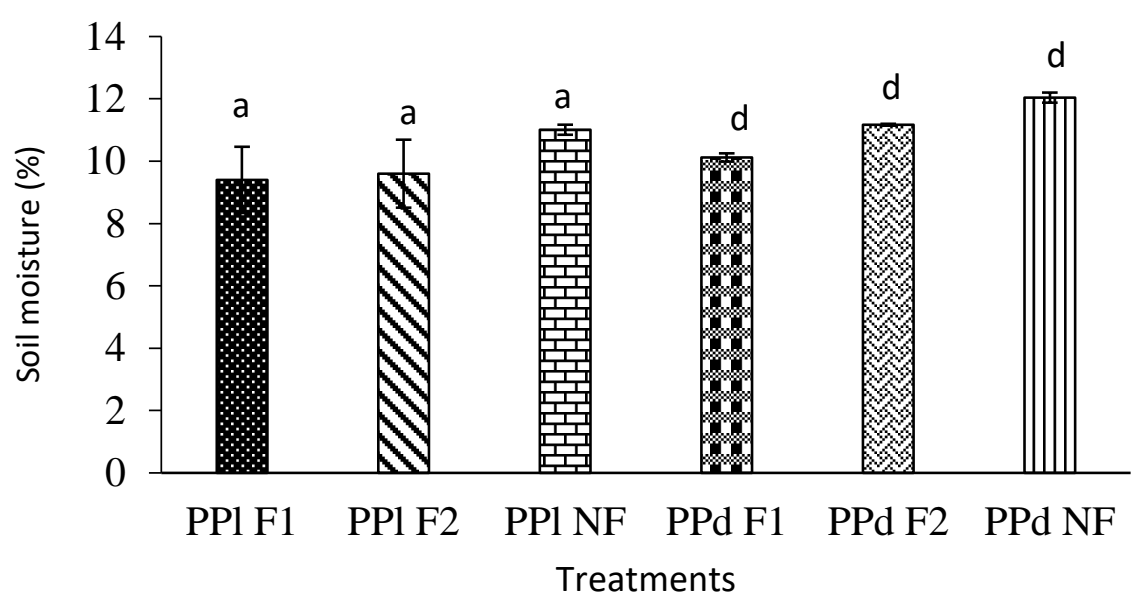

Fig 1. The soil moisture content of PPI underdiferent treatments. Different letters (a-c) showed significantly different $(p<0.05$, ANOVA). For PPd with diferent treatments, different letters ( $d-f)$ showed significantly different $(p<0.05$, ANOVA).

Table 2. Properties of the soils used in this study.

\begin{tabular}{ll}
\hline Parameters & Results \\
\hline pH H2O (1:2.5; w/v) & 4.1 \\
Soil organic matter (\%) & 3.2 \\
Soil moisture content (\%) & 20.8 \\
Sand (\%) & 51 \\
Clay (\%) & 33 \\
Silt (\%) & 16 \\
Soil Texture & Sandy clay loam \\
K (mg/kg) & 29.76 \\
P (mg/g) & 0.032 \\
Total Nitrogen (\%) & 0.40 \\
\hline
\end{tabular}

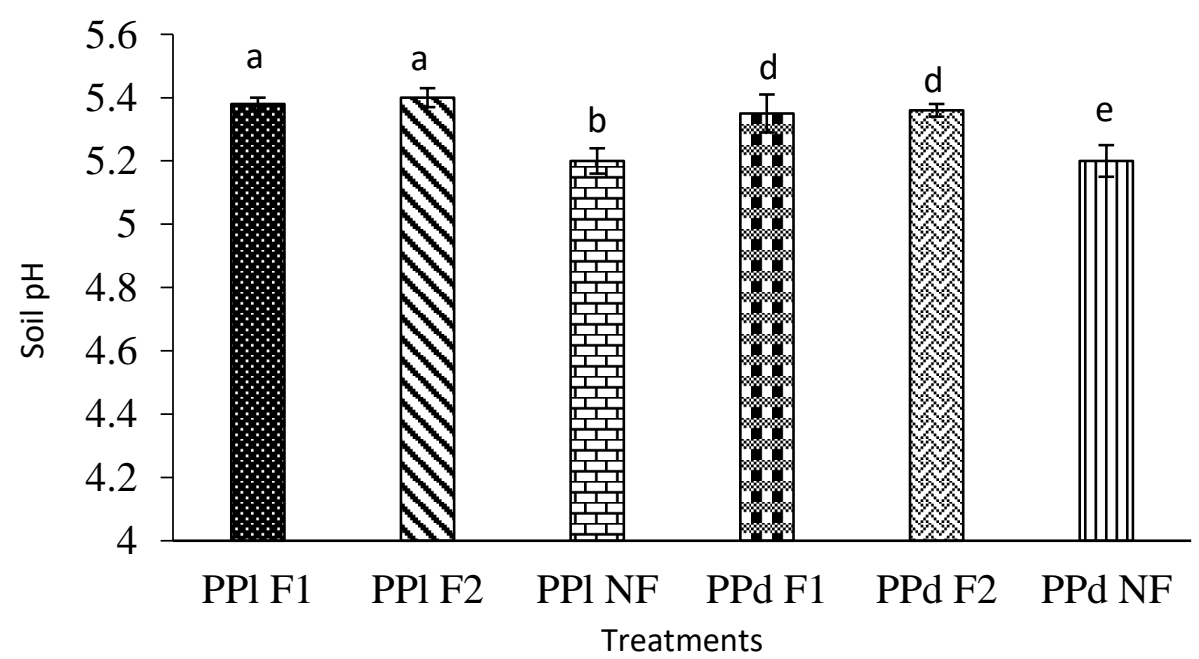

Fig 2. Soil pH under different treatments. Different letters were significantly different $(p<0.05$, ANOVA). 
Table 3. The experimental design with different treatment on two species.

\begin{tabular}{lll}
\hline Treatment & \multicolumn{2}{c}{ Species } \\
\cline { 2 - 3 } & $\mathrm{PPI}$ & $\mathrm{PPd}$ \\
\hline $\mathrm{F}_{1}$ & $\mathrm{n}=4$ & $\mathrm{n}=4$ \\
$\mathrm{~F}_{2}$ & $\mathrm{n}=4$ & $\mathrm{n}=4$ \\
$\mathrm{NF}$ & $\mathrm{n}=4$ & $\mathrm{n}=4$ \\
\hline $\mathrm{n}$ : number of replicates. & &
\end{tabular}

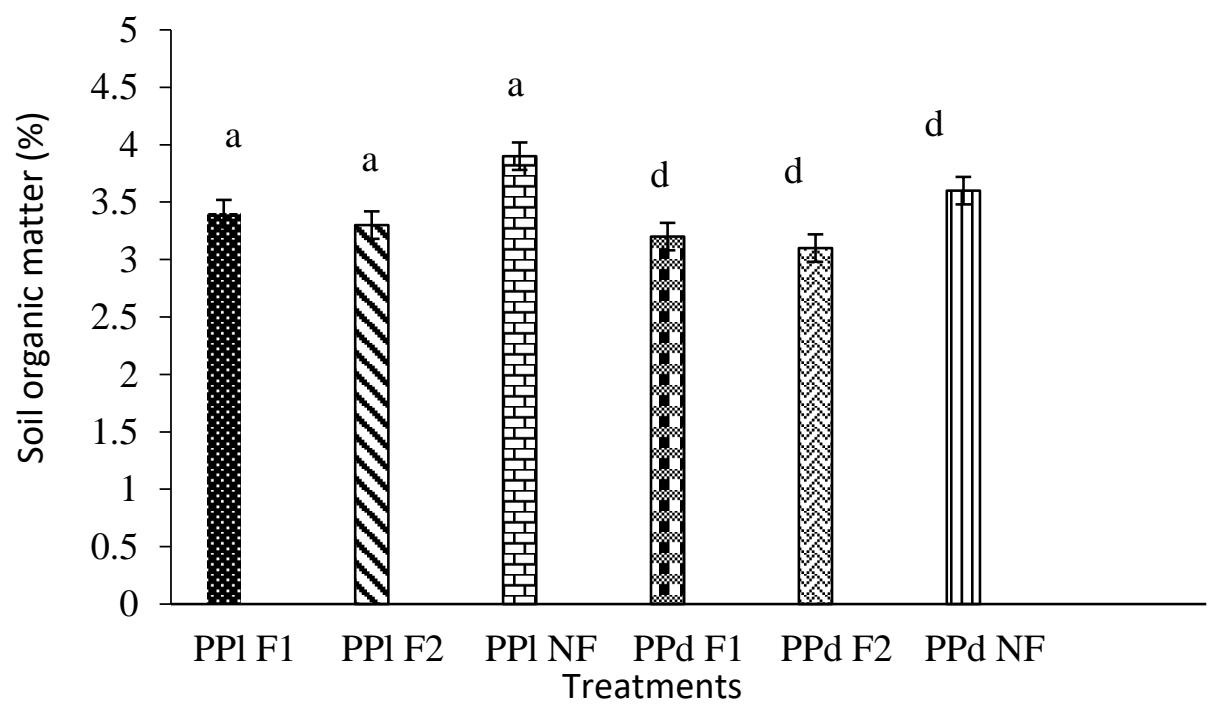

Fig 3. Soil organic matter in a soil under different treatments. Different letters were significantly different $(p<$ 0.05, ANOVA).

Table 4. Physical and chemical properties of NPK fertilizers used in the experiment.

\begin{tabular}{llll}
\hline Properties & Unit & $\mathrm{F}_{1}(10: 8: 10)$ & $\mathrm{F}_{2}(5: 5: 7)$ \\
\hline $\mathrm{pH}$ & - & $6.43 \pm 0.01$ & $6.67 \pm 0.01$ \\
Moisture & $\%$ & $15.62 \pm 0.49$ & $19.69 \pm 0.55$ \\
Organic matter & $\%$ & $48.23 \pm 0.06$ & $48.29 \pm 1.67$ \\
Total C & $\%$ & $11.25 \pm 2.5$ & $7.96 \pm 2.51$ \\
$\mathrm{~N}$ & $\%$ & $2.27 \pm 0.31$ & $1.66 \pm 0.20$ \\
$\mathrm{P}^{-3}$ & $\mathrm{~g} \mathrm{~kg}^{-1}$ & $11.30 \pm 0.30$ & $7.33 \pm 0.33$ \\
$\mathrm{~K}^{+1}$ & $\mathrm{~g} \mathrm{~kg}^{-1}$ & $12.24 \pm 0.05$ & $5.90 \pm 0.03$ \\
$\mathrm{Ca}^{+2}$ & $\mathrm{mg} \mathrm{kg}^{-1}$ & $13.02 \pm 0.22$ & $4.36 \pm 0.33$ \\
$\mathrm{Mg}^{+2}$ & $\mathrm{mg} \mathrm{kg}^{-1}$ & $9.47 \pm 0.47$ & $19.47 \pm 0.47$ \\
$\mathrm{Fe}^{+2}$ & $\mathrm{mg} \mathrm{kg}^{-1}$ & $0.07 \pm 0.0003$ & $0.02 \pm 0.0015$ \\
$\mathrm{Na}^{+1}$ & $\mathrm{mg} \mathrm{kg}^{-1}$ & $12.73 \pm 0.23$ & $6.60 \pm 0.10$ \\
$\mathrm{Cu}^{+2}$ & $\mathrm{mg} \mathrm{kg}^{-1}$ & $0.14 \pm 0.0065$ & $0.15 \pm 0.001$ \\
$\mathrm{Zn}^{+2}$ & $\mathrm{mg} \mathrm{kg}^{-1}$ & $0.63 \pm 0.0405$ & $0.77 \pm 0.032$ \\
$\mathrm{Cd}^{+2}$ & $\mathrm{mg} \mathrm{kg}^{-1}$ & $0.04 \pm 0.0015$ & $0.06 \pm 0.004$ \\
$\mathrm{Ni}^{+2}$ & $\mathrm{mg} \mathrm{kg}^{-1}$ & $0.23 \pm 0.039$ & $0.23 \pm 0.009$ \\
$\mathrm{Co}^{+2}$ & $\mathrm{mg} \mathrm{kg}^{-1}$ & $0.04 \pm 0.0045$ & $0.07 \pm 0.016$ \\
$\mathrm{As}^{-3}$ & $\mathrm{mg} \mathrm{kg}^{-1}$ & $0.02 \pm 0.002$ & $0.02 \pm 0.002$ \\
$\mathrm{~Pb}^{+2}$ & $\mathrm{mg} \mathrm{kg}^{-1}$ & $0.04 \pm 0.0025$ & $0.05 \pm 0.002$ \\
$\mathrm{~B}^{+3}$ & $\mathrm{mg} \mathrm{kg}^{-1}$ & $0.08 \pm 0.0075$ & $0.04 \pm 0.035$ \\
$\mathrm{Mo}^{+2}$ & $\mathrm{mg} \mathrm{kg}^{-1}$ & $0.018 \pm 0.005$ & $0.01 \pm 0.0001$ \\
$\mathrm{Si}^{+4}$ & $\mathrm{mg} \mathrm{kg}^{-1}$ & $0.55 \pm 0.028$ & $0.69 \pm 0.069$ \\
\hline
\end{tabular}

Table 5. Predetermined amount of hydroseeding mixture.

\begin{tabular}{lc}
\hline Materials & Amounts \\
\hline Seed & $27.5 \mathrm{~g} / \mathrm{m}^{2}$ \\
Paper mulch & $125 \mathrm{~g} / \mathrm{m}^{2}$ \\
Soil tacifier & $50 \mathrm{ml} / \mathrm{m}^{2}$ \\
Fertilizer & $31.25 \mathrm{~g} / \mathrm{m}^{2}$ \\
Water & $1.68 \mathrm{~L} / \mathrm{m}^{2}$ \\
Average $\mathrm{pH}$ & 5.48 \\
\hline
\end{tabular}




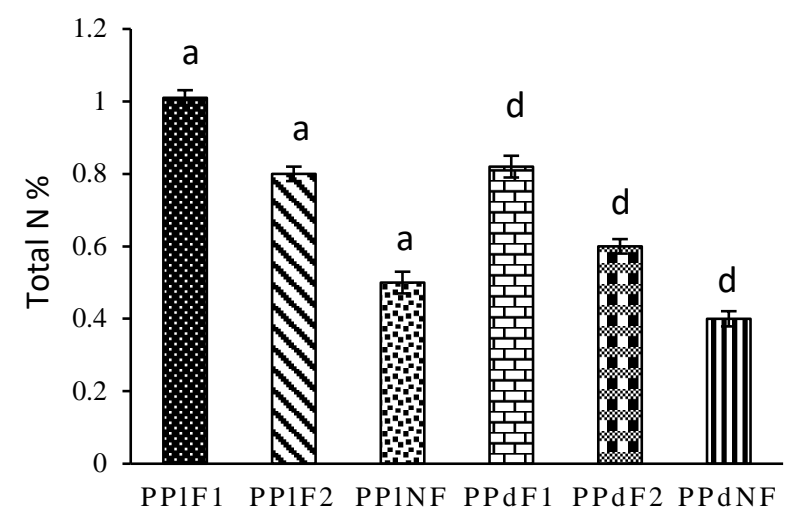

Treatments

(a)

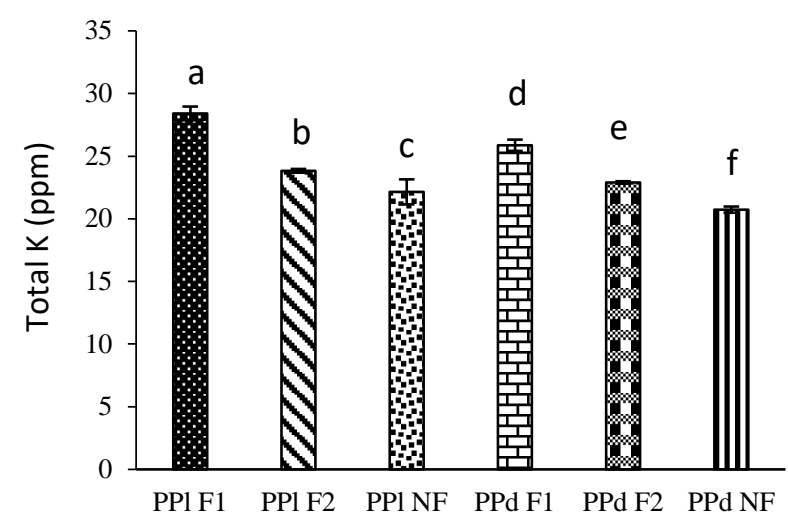

Treatments

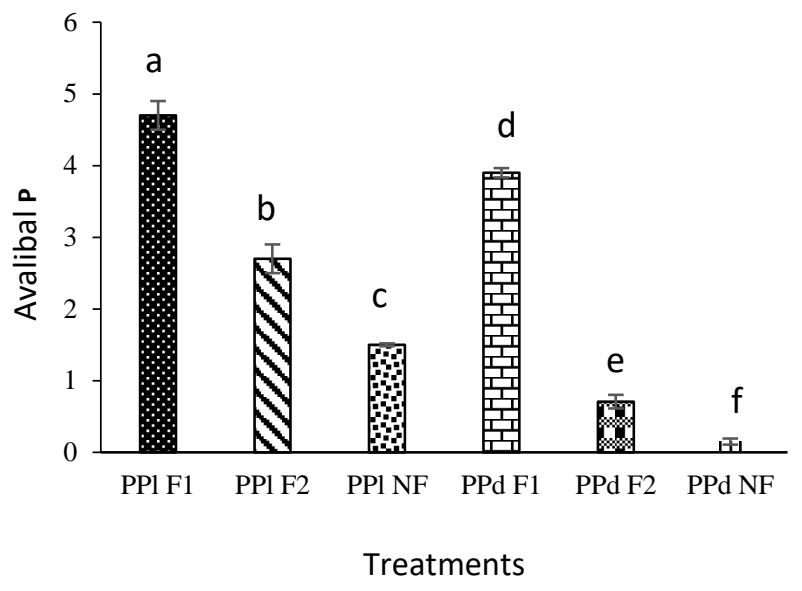

(b)

(c)

Fig 4. The nutrient availability after 6 month observation period (a) Total nitrogen (b) Phosphorus and (c) Total Potassium. Different letters were significantly different ( $p<0.05$, ANOVA).

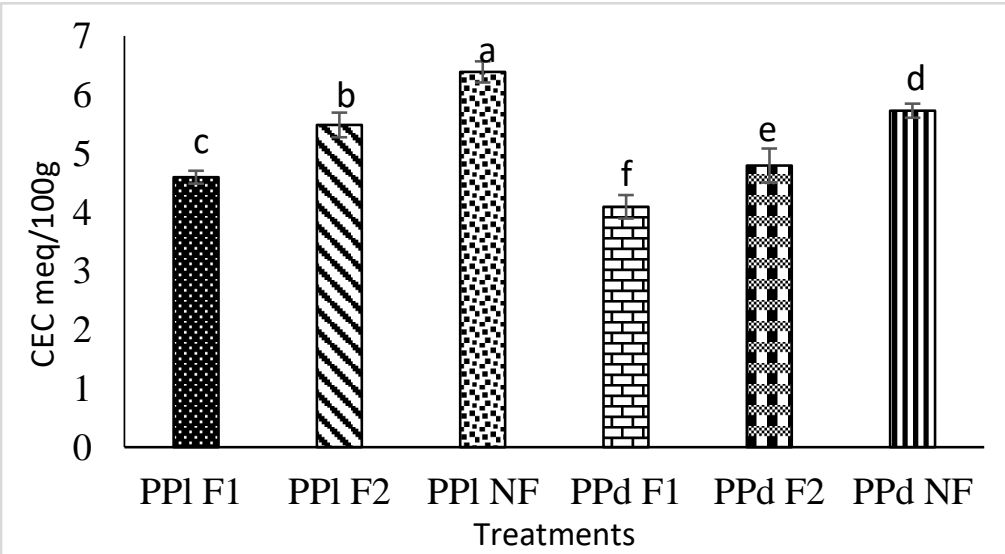

Fig 5. Soil CEC under different treatments. Different letters were significantly different $(p<0.05, A N O V A)$. 


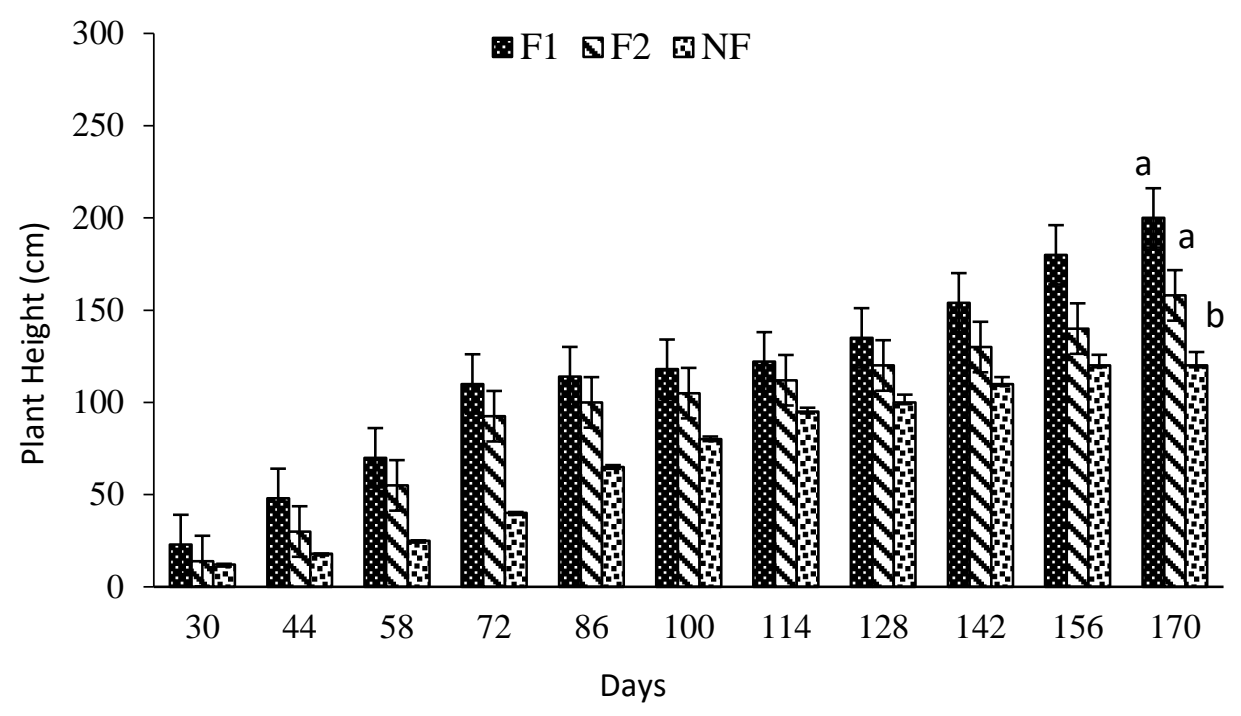

(a)

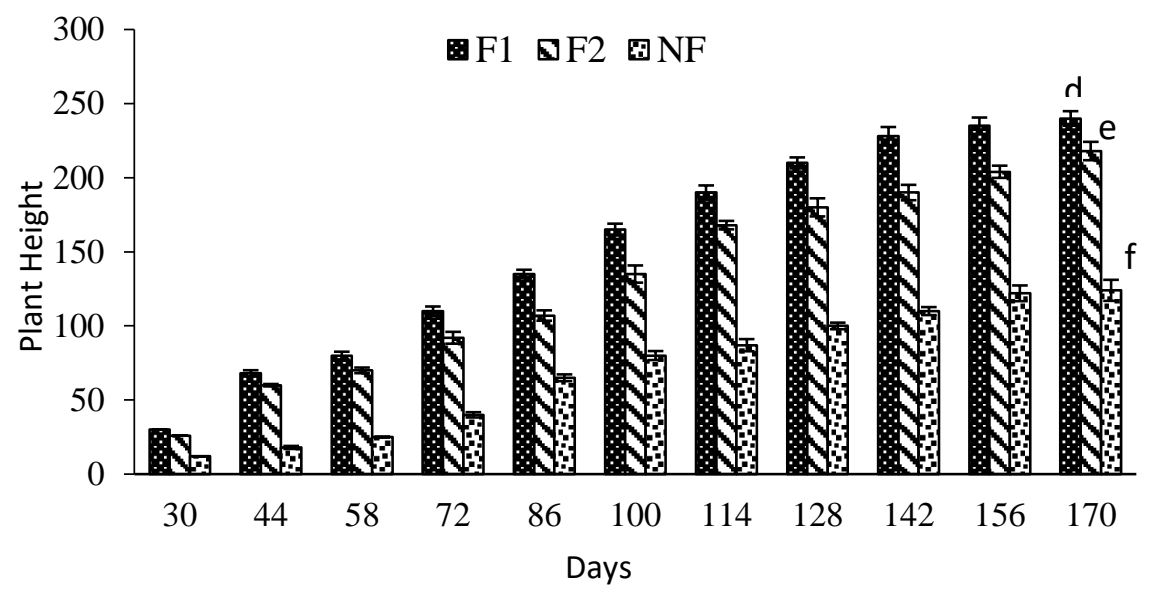

(b)

Fig 6. Increment in height of Pennistium sp. in three different treatments (a) PPI species (b) PPd species. Different letters were significantly different $(p<0.05$, ANOVA) after six months.

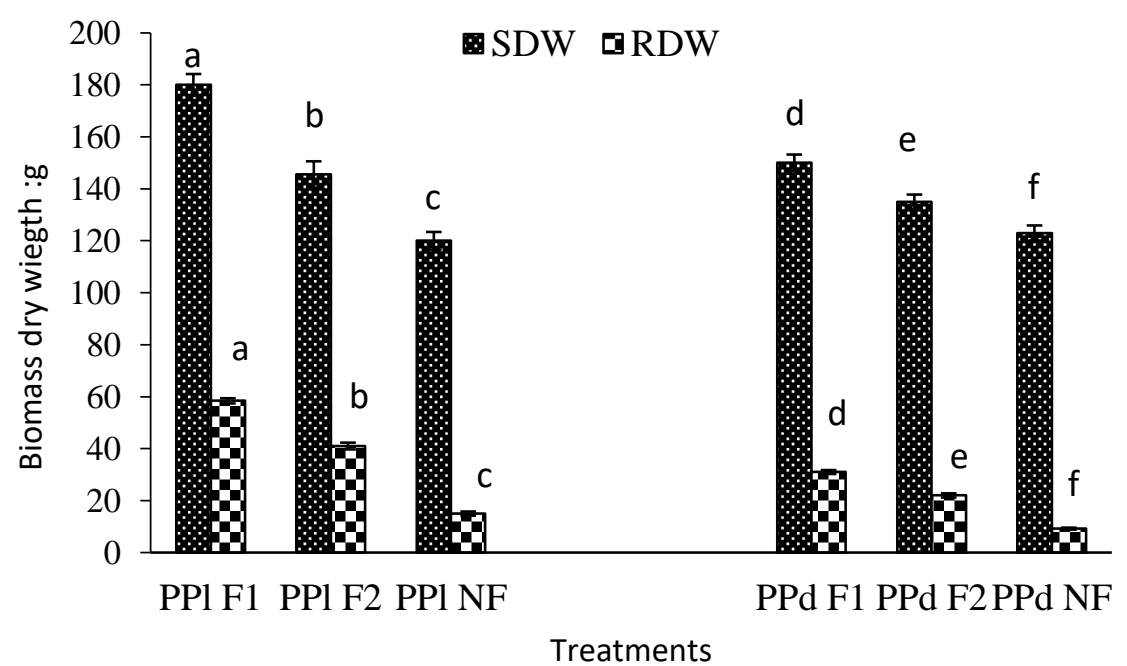

Fig 7. Results of the shoot dry weight (SDW) and root dry weight (RDW). Different letters were significantly different $(p<0.05$, ANOVA). 


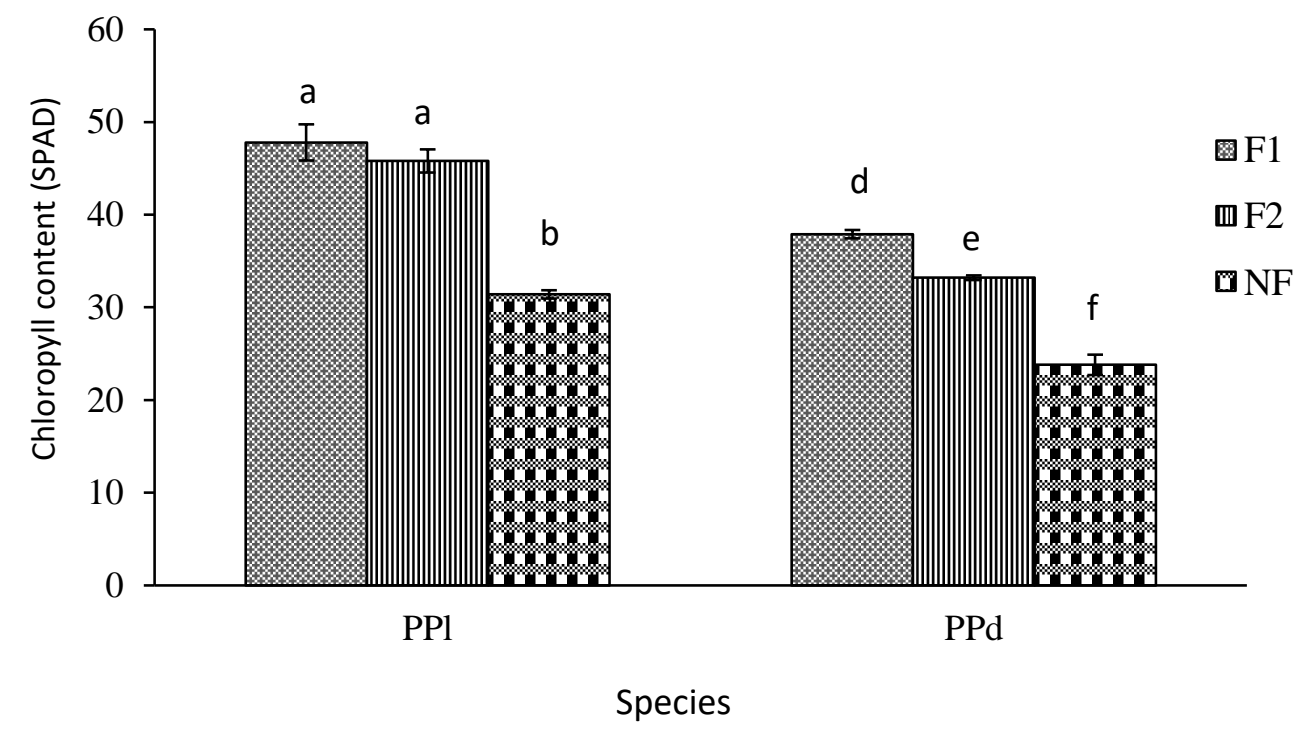

Fig 8. The chlorophyll content was recorded during the 6th month of two species with 3 different treatments:(PPI with $F_{1}, F_{2}$ and $N F, P P d$ with $F_{1}, F_{2}$ and $N F$ ).

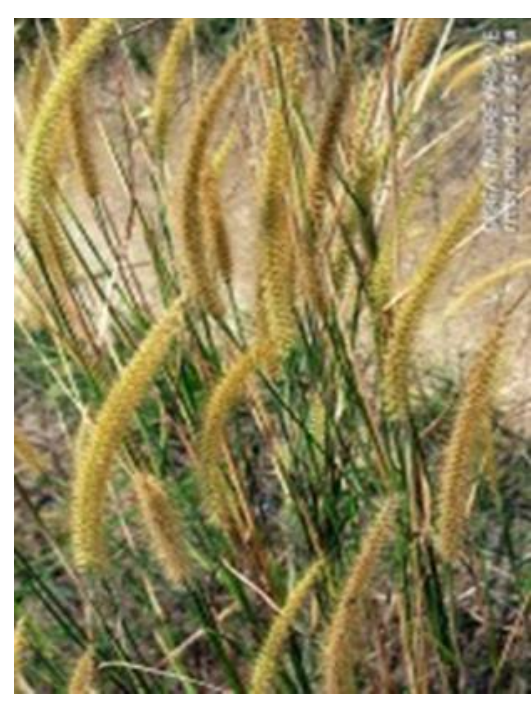

(a)

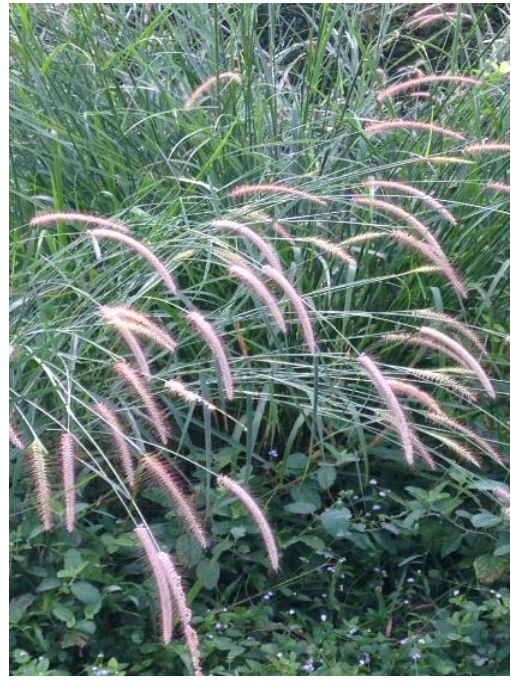

(b)

Fig 9. The Pennisetum species used in this study (a) P. polystachion, and (b) P. peddicelatum (PPd)

indicated higher $\mathrm{P}$ content, if compared to that of $\mathrm{F}_{2}$ treatment and NF (Figure 4b). High $P$ levels in the fertilizer may have led to high soil $P$ availability with $F_{1}$. Following direct utilization of compost originally extracted from daily manure, a significant rise in concentrations of $\mathrm{P}$ and other nutrients in soil were seen (Butler et al., 2008; Soumare et al., 2003). In addition, solubility of $P$ in the soil was heavily influenced by mineral fertilizer added with the $P$ source (Leytem and Westermann, 2005a; Leytem et al., 2005b; Leytem and Bjorneberg, 2009).

The total level of $K$ was recorded after the plant species were harvested (Figure 4c). The level of $\mathrm{K}$ was higher for species treated with $F_{1}$, compared to species treated with $F_{2}$ and untreated species NF. Likewise, the ratio of NPK in fertilizers used for different species influenced the presence of $\mathrm{K}$ in the soil. However, plant uptakes, runoff, soil erosion and leaching can increase the tendency of $\mathrm{K}$ levels to drop (Basak and Biswas, 2009). Statistically, the $P$ and $K$ concentrations were significant $(p<0.05)$ in both species. In contrast, the nitrogen concentration did not show significant difference $(p>0.05)$ in all treatments.

\section{Cation exchange capacity (CEC)}

The cation exchange capacity (CEC) of the soil in different treatments ranged from 4.09 to $6.38 \mathrm{meq} / 100 \mathrm{~g}$ (Figure 5). The CEC value for PPI species treated with $F_{1}$ and $F_{2}$ were mostly higher than PPd species. Meanwhile the species treated with $F_{1}$ showed the lowest value, compared to that of species treated with $\mathrm{F}_{2}$. For NF, the both species of PPI and PPd showed the highest CEC values of $6.38 \mathrm{meq} / 100 \mathrm{~g}$ and $5.72 \mathrm{meq} / 100 \mathrm{~g}$, respectively. The highest value of CEC in these treatments could be attributed to the high soil organic content in these treatments (Figure 3). Similarly, a study by Wang et al. (2005) reported that a positive correlations existed between the soil CEC and soil organic content. On 
the other hand, Han et al. (2016) revealed that the soil CEC was reduced after cultivation of yellow poplar (Liriodendron tulipifera Lin.) under NPK treatment. However, the value of CEC in this study is considered low, which can be attributed to the sandy texture of soils. For PPI and PPd, the CEC was not significant difference $(p>0.05)$ in all treatments.

\section{Plant height and total biomass}

The results of the plant height for the two species were shown in Figure $6 \mathrm{a}$ and $6 \mathrm{~b}$. The height patterns for both species indicated the impact of distinct ratios of NPK fertilizers. PPI species treated with $F_{1}$ showed higher value in terms of height, when compared to those PPI treated with $\mathrm{F}_{2}$ (Figure 6a). Meanwhile, PPI species without treatment (NF) showed the lowest values of plant height, compared to $F_{1}$ and $F_{2}$ treatments. On the other hand, PPd species, treated with $F_{1}$ and $F_{2}$ showed higher value compared to PPI species (Figure 6b). However, PPd treated with $F_{1}$ exhibited higher values of plant height than species treated with $F_{2}$. Plant height of two species was significantly $(p>0.05)$ affected by different treatments. Comparison between PPI and PPd species for both treatments in terms of increment percentage of plant height after 6 months, compared to NF (control) were as shown in Table 1. A progressive development in terms of plant height was attributed to the increase in nitrogen content, which promoted plant growth by increasing the length and number of internodes (Gasim, 2001). The inorganic nitrogen was the major compound absorbed by most plants, despite the small amounts of its present (i.e., $\mathrm{NH}^{+}, \mathrm{NO}^{-}$, and $\mathrm{NO}^{-}$) out of the soil's total nitrogen (Brady and Weil, 2008; Liu et al., 2014).

The total biomass (shoot dry weight and root dry weight) measured at the end of the observation was as shown in Figure 7. Generally the highest value of biomass production was demonstrated by PPI species treated by $F_{1}(238.4 \mathrm{~g})$. The $F_{1}$ treatment was also attributed to the highest biomass production in PPd species (Figure 7). As expected, the lowest production can be seen in both species treated with NF. The result suggested that the biomass production can be related to the ratio of NPK used in the treatment. The shoot dry weight and root dry weight were significantly difference ( $p>$ 0.05 ) in both species (figure 7). A previous study by Shubhashree, (2007) concluded that total biomass production can be increased by increasing the phosphorus content. This increase in biomass production can be attributed to the increase in the number of branches per plant as a result of adequate supply of $P$ (Turuko and Mohammed, 2014).

\section{Leaf chlorophyll content}

One of the most significant factors affecting plant growth is the content of leaf chlorophyll. It participates in the biosynthesis process called photosynthesis, which synthesizes organic compounds from basic substances (Rong-hua et al., 2006; Skwaryło-Bednarz and Krzepiłko, 2009). The chlorophyll content (SPAD) of the PPd species was lower than the PPI species (Figure 8). For $F_{1}$ treatment, the measured chlorophyll content (SPAD) was 45.7 SPAD for PPd species and 52.2 SPAD for PPI species. Meanwhile, the chlorophyll content recorded for PPd and PPI species applying $F_{2}$ treatment, were 41.9 and 47.0 SPAD, respectively. As projected, the lowest value of chlorophyll content was evident in both untreated species of PPd and PP1 (36.6 and 38.4 SPAD, respectively). Statistically, the leaf chlorophyll content was significantly high $(p<0.05)$ in both species. Many studies suggested that fertilization with macro elements especially nitrogen raise the chlorophyll content in plants significantly (Kolodziej, 2006; Hokmalipour and Darbandi, 2011). This observation showed that $F_{1}$ treatment has greater ratio of nitrogen than $F_{2}$ treatment, resulting in greater level of chlorophyll in both species. Earlier researches also suggested the close link between nitrogen content and chlorophyll (Filed and Moony, 1986; Almaliotis et al., 1997).

As illustrated in Figure 7, more production of dry biomass was evident for PPI in these treatments $\left(F_{1}\right.$ and $\left.F_{2}\right)$, which suggested that nitrogen level available in distinct ratios links with more leaf chlorophyll content (Figure 8). A previous study by Fitzgerald et al. (2010) showed that there is a strong correlation between chlorophyll concentration and nitrogen content in wheat leaves.

\section{Materials and Methods}

\section{Soil medium and NPK fertilizer}

This study was conducted under glasshouse conditions (temperature of $21-32{ }^{\circ} \mathrm{C}$, average $12 \mathrm{~h}$ photoperiod and relative humidity of $60-90 \%)$. Table 2 summarized the initial chemical and physical properties of soil medium used in this study. The soil medium was characterized as sandy clay loam ( $16.3 \%$ silt, $32.6 \%$ clay and $51 \%$ sand). $\mathrm{pH}$ of the soil is highly acidic with moisture and organic contents of $21 \%$ and $3.2 \%$, respectively. This study was performed for six months duration which involved the monitoring of growth performance parameters of the studied species. The soil characteristics were also determined for comparision purpose after six months of monitering.

The experiment was conducted in a $3 \times 2$ factirial design ( 3 treatments $X 2$ species) with four replicates (Table 3 ). Each species of pennisetum received three different treatments known as $F_{1}(N P K=10: 8: 10), F_{2}$ (NPK=5:5:7) and NF (no NPK) treatments. The physical and chemical properties of NPK fertilizers were shown in Table 4. It was found that the $\mathrm{N}$ contents were $2.27 \%$ and $1.66 \%$ for $F_{1}$ and $F_{2}$, respectively. Phosphate $(P)$ content was higher in $F_{1}\left(11.6 \mathrm{gkg}^{-1}\right)$ than $F_{2}$ $\left(7.6 \mathrm{gkg}^{-1}\right)$. A similar trend was also present for potassium (K). All the heavy metals were found to have small concentration (Table 4). The amount of fertilizers was 31.25 $\mathrm{g} / \mathrm{m} 2$ in order to assess its influence on Pennisetum sp.'s growth performance.

\section{Plant materials and hydroseeding mixture}

This study selected two localized grass species Pennisetum pedicellatum (PPd) and Pennisetum polystachion (PPI). The colours of their spikelets differentiate these species, where the spikelet of PPd was reddish while the PPI was yellow (Figure 9a and 9b). The time for collection of matured seeds was based on their spikelet's colour, reddish brown for PPd and yellowish brown for PPI. Collections of seed for both species were carried out near the glasshouse facility located in University Kebangsaan Malaysia (Bangi, Malaysia), since 
these species are widely distributed especially on sloping ground and recently opened areas.

Hydroseeding method was applied in this study to sow the seed. A mixture of soil tacifier, seed, water, fertilizer and paper mulch made up the hydroseeding mixture. The standard process proposed by the supplier, Hydroturf Services (M) Sdn. Bhd was utilized to calculate the amount of each portion. Soak recycled paper in plastic containers filled with water for several days. The water was continuously changed every 24 hours until the $\mathrm{pH}$ became neutral. The soaked papers were then blended and dried in the oven at $70^{\circ} \mathrm{C}$ for a duration of 7 days. The predetermined paper mulch and seed were mixed with water and left for a duration of 36 hours. Next, the soil tacifier and NPK fertilizer were added and the mixture was mixed again until it had a slurry texture. Approximately, 25 $\mathrm{kg}$ soil was used to fill a polybag with dimensions of $24 \mathrm{~cm}$ height and $22 \mathrm{~cm}$ diameter. The amounts of seed, soil tacifier, paper mulch, water and fertilizer was calculated based on the surface area covered by soil medium in the polybag (Table 5). The soil medium was then top-dressed with hydro mulching mixture according to different treatments. Both species were routinely watered twice a day at 9.00 am and $5.00 \mathrm{pm}$ for six months period.

\section{Soil Physico-chemical properties}

Representative soil samples before and after treatments were collected at a depth of $10 \mathrm{~cm}$ from each polybags. The soil samples were kept in labelled plastic bags for further analysis. The samples were first air-dried, manually crushed and filtered through a $2 \mathrm{~mm}$ sieve. The parameters involved were soil nutrient availability, water and organic contents, particle size distribution, $\mathrm{pH}$ and cation exchange capacity (CEC). The $\mathrm{pH}$ of soil was determined based on the 1:2.5 soilwater solution. Pipet technique was used to perform the particle size distribution analysis. Gravimetric approach was used to determine soil moisture, while ignition method was used to determine organic matter level. These parameters were ascertained in accordance to the standard approach within the provisions of the British Standard Institution 1377 (1990) Part 2. Kjeldahl approach was used to determine the total N, while Atomic Absorption Spectrophotometer (AAS) was used to determine the total $\mathrm{K}$. The Ultra Violet Spectrophotometer Vis UV 1201 model at $660 \mathrm{~nm}$ was utilized to ascertain the nutrient availability of $P$ (Murphy and Riley, 1962). Meanwhile, CEC was determined by using Flame Atomic Absorption Spectrophotometry (FAAS).

\section{Plant height and total biomass}

The plant height was measured from soil surface to the apical portion of plant and expressed in centimeters. The measurement of biomass was performed at the end of the monitoring stage. The plant samples were carefully uprooted from the polybags and cleaned with water to remove any dirt from the samples. The plant samples were then kept in the oven for 48 hours at temperature of $60^{\circ} \mathrm{C}$ before weighted with balance model Mettle PJ3000 (Japan).

\section{Leaf chlorophyll content}

The chlorophyll content of the leaf was tested using portable chlorophyll meter (SPAD-502 Minolta Co. Ltd., Osaka Japan). The measurement was started at two months after hydroseeding and was continuously monitored every month up to six months. The leaf selected for chlorophyll content was at the $2 / 3$ position from the leaf based on the apex of a fully expended leaf to obtain the optimum chlorophyll content (Yuan et al., 2016).

\section{Statistical analysis}

The data was statistically analysed using SPSS (version 21). One way ANOVA was applied to determin the significant differences between the applied treatments in this study. the Least Significant Difference (LSD) was used, the effect of treatment considered significantly at $\mathrm{P}<0.05$.

\section{Conclusion}

The soil $\mathrm{pH}$ and soil organic content were slightly increased after 6 months of observation. The $\mathrm{N}$ and $\mathrm{P}$ contents also increased, whilst $K$ content decreased in $F_{1}$ and $F_{2}$ treatment for both species. The PPd species treated with $F_{1}$ and $F_{2}$ showed higher plant height parameter than PPI species. However, both species showed higher values of plant height when treated with $F_{1}$ compared to $F_{2}$. A similar result was also observed for dry biomass value in species treated with $F_{1}$. Conclusively, PPI species treated with $F_{1}$ clearly showed higher value in all growth performance variables (height, dry biomass and chlorophyll content), if compared to that of $F_{2}$ treatment. This can be associated with the higher ratio of NPK available in $F_{1}$ treatment (10:8:10). Therefore, Pennisetum polystatchion (PPI species) treated with $\mathrm{F}_{1}$ can be a potential biological material for slope vegetation in slope protection against soil erosion.

\section{Acknowledgement}

The researchers would like to thank Universiti Kebangsaan Malaysia for the research grant (GUP-2016-068) throughout this project. The researchers are also grateful the technical staff for assisting in sample preparation and laboratory testing.

\section{References}

Acres BD, Bower RP, Borrough PA, Folland CJ, Kalsi MS (1975) The Soils of Sabah. Volume 1: classification and description. Land Resource Study 20, Ministry of Overseas Development, UK. 135 pp.

Almaliotis D, Therios I, Karatissiou M (1997) Effect of nitrogen fertilization on growth, leaf nutrient concentration and photosynthesis in three peach cultivars. II International Symposium on Irrigation of Horticultural Crops. ISHS Acta Hort. 449(2): 529-534.

Barry DAJ, Miller MH (1989) Phosphorus nutritional requirement of maize seedlings for maximum yield. Agron J. 81(1): 95-99. 
Basak BB, Biswas DR (2009) Influence of potassium solubilizing microorganism (Bacillus mucilaginosus) and waste mica on potassium uptake dynamics by sudan grass (Sorghum vulgare Pers.) grown under two Alfisols. Plant Soil. 317(1): 235-255.

Benbi DK, Brar JS (2009) A 25-year record of carbon sequestration and soil properties in intensive agriculture. Agron Sustain Dev. 29(2): 257-265.

Brady NC, Weil RR (2008) Soil Colloids: Seat of Soil Chemical and Physical Acidity. In The Nature and Properties of Soils; Brady, N.C., Weil, R.R., Eds.; Pearson Education Inc.: Upper Saddle River, NJ, USA,; pp. 311-358.

British Standard Institution.1990. Methods of test for Soils for civil engineering purposes- Part2: Classification Tests. BS1377, London.

Butler TJ, Han KJ, Muir JP, Weindorf DC, Lastly L (2008) Dairy manure compost effects on corn silage production and soil properties. Agron J. 100(6): 1541- 1545.

Cairns MA, Brown S, Helmer EH, Baumgardner GA (1997) Root biomass allocation in the world's upland forests. Oecol. 111(1):1-11.

Cereno MM, Tan FJ, Uy FAA (2011) Combined hydroseeding and coconet reinforcement for soil erosion control. In D. Godone, Soil Erosion Studies. pp. 213-226.

Cheng H, Zhang XQ (2002) An experimental study on herb plant root system for strength principle of soil fixation. Bulletin of Soil and Water Conservation. 22(5): 20-23.

EL-Desuki M, Mahmoud AR, Hafiz MH (2006) Response of onion plants to mineral and biofertilizers application. Res J Agric Biological Sci. 2(6): 292-298.

Epstein E (1997) The science of composting. Technomic Pub. Co., Lancaster PA, p487.

Fageria NK, He Z, Baligar VC (2017) Phosphorus management in crop production. CRC Press.

Field C, Mooney HA, (1986) The photosynthesis - nitrogen relationship in wild plants. - In: On the economy of plant form (GIVNISH T. J., Ed.). Cambridge, University Press, 2553.

Fitzgerald G, Rodriguez D, O'Leary G (2010) Measuring and predicting canopy nitrogen nutrition in wheat using a spectral index - the canopy chlorophyll content index (CCCI). Field Crop Res. 116(3): 318-324.

Garcia-Gil JC, Ceppi SB, Velasco MI, Polo A, Senesi N (2004) Long-term effects of amendment with municipal solid waste compost on the elemental and acidic functional group composition and $\mathrm{pH}$-buffer capacity of soil humic acids. Geoderma. 121(1): 135-142.

Gasim SH (2001) Effect of nitrogen, phosphorus and seed rate on growth, yield quality of forage maize (Zea mays L.). M.Sc Thesis. Faculty of Agric Univ Khartoum.

Grant CA, Flaten DN, Tomasiewicz DJ, Sheppard SC (2001) The importance of early season phosphorus nutrition. Can J Plant Sci. 81(2):211-224.

Grimhaw RG (1994) Vetiver grass-Its use for slope and structural stabilization under tropical and semi-tropical conditions. In: Vegetation and slopes. Institution of Civil Engineers, London, pp. 26-35.

Ismail BS, Tan PW, Chuah TS (2015) Assessment of the potential allelopathic effects of Pennisetum purpureum Scumach. on the germination and growth of Eleusine indica (L.) Gaertn. Sains Malays. 44(2): 269-274.
Ismail BS, Tan PW, Nornasuha Y (2018) Herbicidal potential of the allelochemicals from Pennisetum purpureum Schumach. on the seedling growth of Paspalum conjugatum. Aust J Crop Sci. 12(2): 173-177.

Han SH, An JY, Hwang J, Kim SB, Park BB (2016) The effects of organic manure and chemical fertilizer on the growth and nutrient concentrations of yellow poplar (Liriodendron tulipifera Lin.) in a nursery system. Forest Sci Technol. 12(3):137- 143.

Hokmalipour S, Darbandi MH (2011) Effects of nitrogen fertilizer on chlorophyll content and other leaf indicate in three cultivars of maize (Zea mays L.). World Appl Sci J. 15(12): 1780-1785.

Huat BBK, Ali FH, Choong FH (2007) Effect of stress history on the volume change behavior of unsaturated residual soil. EJGE. Volume $12 \mathrm{D}$.

Hubbard RK, Bosch DD, Morshall LK, Strickland TC, Rowland D, Griffin TS, Honeycutt CW, Albrecht SL, Sistani KR, Torbert HA, Wienhold B.J, Woodbury BL, Powell JM (2008) Nitrogen mineralization from broiler litter applied to southeastern Coastal Plain Soils. J Soil Water Conserv. 63(4): 182-192.

Kang S, Hu X, Li Z, Jerie P (2002) Soil water distribution, water use and yield response to partial rootzone drying under shallow groundwater conditions in a pear orchard. Sci Hort. 92(3): 277-291.

Kjeldahl JT (1883) A new method for the determination of nitrogen in organic matter. $Z$ Anal Chem. 22: 366.

Kolodziej B (2006) Effect of mineral fertilization on ribwort plantain (Plantagolanceolata L.) yielding. Acta Agrophys. 8(3): 637-647.

Kong X, Lin W, Hao H (2003) A preliminary experiment on slope rehabilitation with vetiver and native plants in South China. Proceedings of the Third International Conference on Vetiver and Exhibition, Guangzhou, China

Lammeranner W, Rauch HP, Laaha G (2005) Implementation and monitoring of soil bioengineering measures at a landslide in the Middle Mountains of Nepal. Plant Soil 278:159-170.

Lampayan RM, Bouman BAM, de Dios JL, Espirity AJ, Soriano JB, Lactaoen AT, Faronilo JE, Thant KM (2010) Yield of aerobic rice in rainfed lowlands of the Philippines as affected by nitrogen management and row spacing. Field Crop Res. 116(1): 165-174.

Leytem AB, Bjorneberg DL (2009) Changes in soil test phosphorus and phosphorus in runoff from calcareous soils receiving manure, compost,and fertilizer application with and without alum. Soil Sci. 174(8): 445- 455.

Leytem AB, Westermann DT (2005a) Phosphorus availability to barley from manures and fertilizers on a calcareous soil. Soil Sci. 170(6): 401-412.

Leytem AB, Turner BL, Raboy V, Peterson KL (2005b) Linking manure properties to phosphorus solubility in calcareous soils: Importance of the manure carbon to phosphorus ratio. Soil Sci Soc Am J. 69(5): 1516-1524.

Liu, C-W, Sung Y, Cheng B-C, Lai, H-Y (2014) Effects of Nitrogen Fertilizers on the Growth and Nitrate Content of Lettuce (Lactuca sativa L.). Int J Environ Res Public Health. 11(4):4427-4440. 
Marinho ACCS, Portela JC, Silva EF, Dias NS, Sousa Júnior FS, Silva AC, Silva JF (2016) Organic matter and physicochemical attributes of a Cambisol under different agricultural uses in a semi-arid region of Brazil. Aust J Crop Sci. 10(1): 32-41.

Matthew RG., Michael AM, Martin MK, Barbara, ER, Gregg MG, Daniel PB (2011) Direct seeding for riparian tree revegetation: Small-scale field study of seeding methods an irrigation techniques. Ecol Eng. 37(6): 864-872.

Mengel K (2007) Potassium. In: Barker AV, Pilbeam DJ (eds) Handbook of plant nutrition. Taylor \& Francis, Boca Raton, pp 91-120

Murphy J, Riley JP (1962) A modified single solution method for the determination of phosphate in natural waters. Anal Chim Acta. 27: 31-36.

Nadeem M, Mollier A, Morel C, Vives A, Prud'Homme L, Pellerin S (2011) Relative contribution of seed phosphorus reserves and exogenous phosphorus uptake to maize (Zea mays L.) nutrition during early growth stages. Plant Soil. 346 (1):231-244.

Narayana R, Fliegmann J, Paponov I, Maffei ME (2018) Reduction of geomagnetic field (GMF) to near null magnetic field (NNMF) affects Arabidopsis thaliana root mineral nutrition. Life Sci Space Res. 19: 43-50.

Normaniza O, Barakabah SS, (2011) The effect of plant succession on slope stability. Ecol Eng. 37:139-147.

Qasim S, Harahap ISH, Osman SBS (2013) Causal factors of Malaysian landslides: A narrative study. Res J Appl Sci Eng Technol. 5(7): 2303-2308.

Rong-hua L, Pei-guo G, Baum M, Grando S, Ceccarelli S (2006) Evaluation of chlorophyll content and fluorescence parameters as indicators of drought tolerance in barley. Agric Sci China. 5(10):751-757.

Schnitzler A, Hale BW, Alsum EM (2007) Examining native and exotic species diversity in European riparian forest. Biol Cons. 138(1): 146-156.

Shubhashree KS (2007) Response of Rajmash (Phaseolus vulgaris $\mathrm{L}$.) to the levels of nitrogen, phosphorus and potassium during rabi in the Northern transition zone. MSc Thesis, Dharwad Universityof Agricultural Science, Dharwad
Singh AK (2010) Bioengineering techniques of slope stabilization and landslide mitigation. Disas Prev Manag. 19(3): 384-397.

Skwaryło-Bednarz B, Krzepiłko A (2009) Effect of various doses of NPK fertilizers on chlorophyll content in the leaves of two varieties of amaranth (Amaranthus cruentus I.). Ecol Chem Eng 16(10): 1373-1378.

Soumare M, Tack FMG, Verloo MG (2003) Effects of a municipal solid waste compost and mineral fertilization on plant growth in two tropical agricultural soils of Mali. Bioresour Technol. 86(1): 15-20.

Turuko M, Mohammed (2014) Effect of different phosphorus fertilizer rates on growth, dry matter yield and yield components of common bean (Phaseolus vulgaris L.). World J Agric Res. 2(3): 88-92.

Tognetti R, Giovannelli A, Lavini A, Morelli G, Fragnito F, d'Andria R (2009) Assessing environmental controls over conductances through the soil-plant-atmosphere continuum in an experimental olive tree plantation of southern Italy. Agric For Meteorol. 149(8): 1229-1243.

Wakeel A, Farooq M, Qadir M, Schubert S (2011) Potassium substitution by sodium in plants. Crit Rev Plant Sci. 30(4): 401-413.

Wang M, Zheng Q, Shen Q, Guo S (2013) The critical role of potassium in plant stress response. Int J Mol Sci. 14(4): 7370-7390.

Wang Q, Li Y, Klassen W (2005) Determination of cation exchange capacity on low to highly calcareous soils. Commun Soil Sci Plan. 36(11): 1479-1498

Yusoff NA, Fauzi MFM, Abdullah F (2016) The study of soilroots strength performance by using Pennisetum setaceum grass. The $3^{\text {rd }}$ International Conference on Civil and Environmental Engineering for Sustainability, EDP Sciences, 47: 1-7.

Yoon PK (1994) Important biological considerations in use of vetiver grass hedgerows (VGHR) for slope protection and stabilization. In: Barker, D.H. (ed.), Vegetation and Slopes: Stabilization, Protection and Ecology, Oxford.

Yuan Z, Ata-Ul-Karim ST, Cao Q, Lu Z, Cao W, Zhu Y, Liu X (2016) Indicators for diagnosing nitrogen status of rice based on chlorophyll meter readings. Field Crop Res. 185: 12-20. 